Ann. rheum. Dis. (1965), 24, 103.

\title{
HEBERDEN ORATION, 1964* \\ SOME IMMUNOLOGIC ASPECTS OF THE CONNECTIVE TISSUE DISEASES
}

\author{
BY \\ M. ZIFF \\ University of Texas Southwestern Medical School
}

\begin{abstract}
The evidence seems strong that, regardless of the underlying cause, immune phenomena are prominent in the connective tissue diseases. But evidence that immune reactions occur provides no assurance that they are causally related to the disease process. I should like, therefore, to explore the immunologic response in these diseases on the basis of three lines of investigation going on in our laboratory, and to discuss with you their bearing on this question. First, I will describe our experiments with homologous disease, an immunologically-induced multisystem disease in the experimental animal; then some electron microscopic studies of the rheumatoid synovial membrane with regard to an anatomical basis for an immune response in this tissue; and finally, a study of the state of two autoantibodies in the serum of patients with connective tissue disease and their significance.
\end{abstract}

\section{Homologous Disease in the Adult Rat}

Suppose we were to create an experimental animal in which a large spectrum of "autoimmune" responses had to occur because of the very nature of the beast. Should we see some of the changes known to us in patients with connective tissue disease? The animal with homologous disease provides this opportunity. In this animal, at least a fraction of the lymphoid cells is derived from a foreign or homologous donor. Under appropriate circumstances, these cells can survive and proliferate, constituting, in essence, a graft of foreign cells. Being foreign, they react immunologically to the antigens of the host. This graft-versus-host reaction is deleterious to the host, which gradually loses weight and usually dies. Accompanying this reaction, we have observed a number of inflammatory lesions which have attracted our interest. This work is largely that of Dr. Peter Stastny, who has

* Delivered in London on December 4, 1964. been assisted by Dr. Thomas Vischer. Dr. V. A. Stembridge has been in charge of the pathological studies.

To produce homologous disease, Sprague-Dawley rats were rendered tolerant at birth by intraperitoneal injection of lymphoid cells from a donor strain of inbred Fischer rats (Stastny, Stembridge, and Ziff, 1963). Homologous disease was then induced by injection of the tolerant recipients at 4 months of age with 200 to 800 million donor lymphoid cells on three occasions. Shortly after the third injection, the following abnormalities began to occur: pancytopenia with positive Coombs reaction, joint and cardiac lesions, a variety of skin lesions, infiltrates in the kidney, and alterations in the lymphoid organs.

Polyarthritis. - Of major interest was the occurrence of a migratory polyarthritis in 39 of seventy animals. It was not noted in any of 43 controls, consisting of non-tolerant recipients of live cells, tolerant recipients of frozen and thawed cells, and tolerant recipients which received no subsequent injections of lymphoid cells. Histologically, the arthritis was characterized by an intense mononuclear inflammatory reaction (Fig. 1, overleaf). This was associated with a proliferation of synovial cells, fibroblasts, and capillaries.

Garditis.-Histological changes were noted in all of 21 hearts which were serially sectioned. Myocarditis was seen in all animals examined, and valvulitis in fifteen. The valves showed oedema, chronic inflammation, and fibrosis (Fig. 2, overleaf). The inflammatory cells were chiefly mononuclear in type, consisting of lymphocytes, macrophages, and plasma cells.

The myocardium was involved principally at the root of the mitral and aortic valves, and here the inflammation was again mononuclear in type. The epicardium. also demonstrated inflammation. 


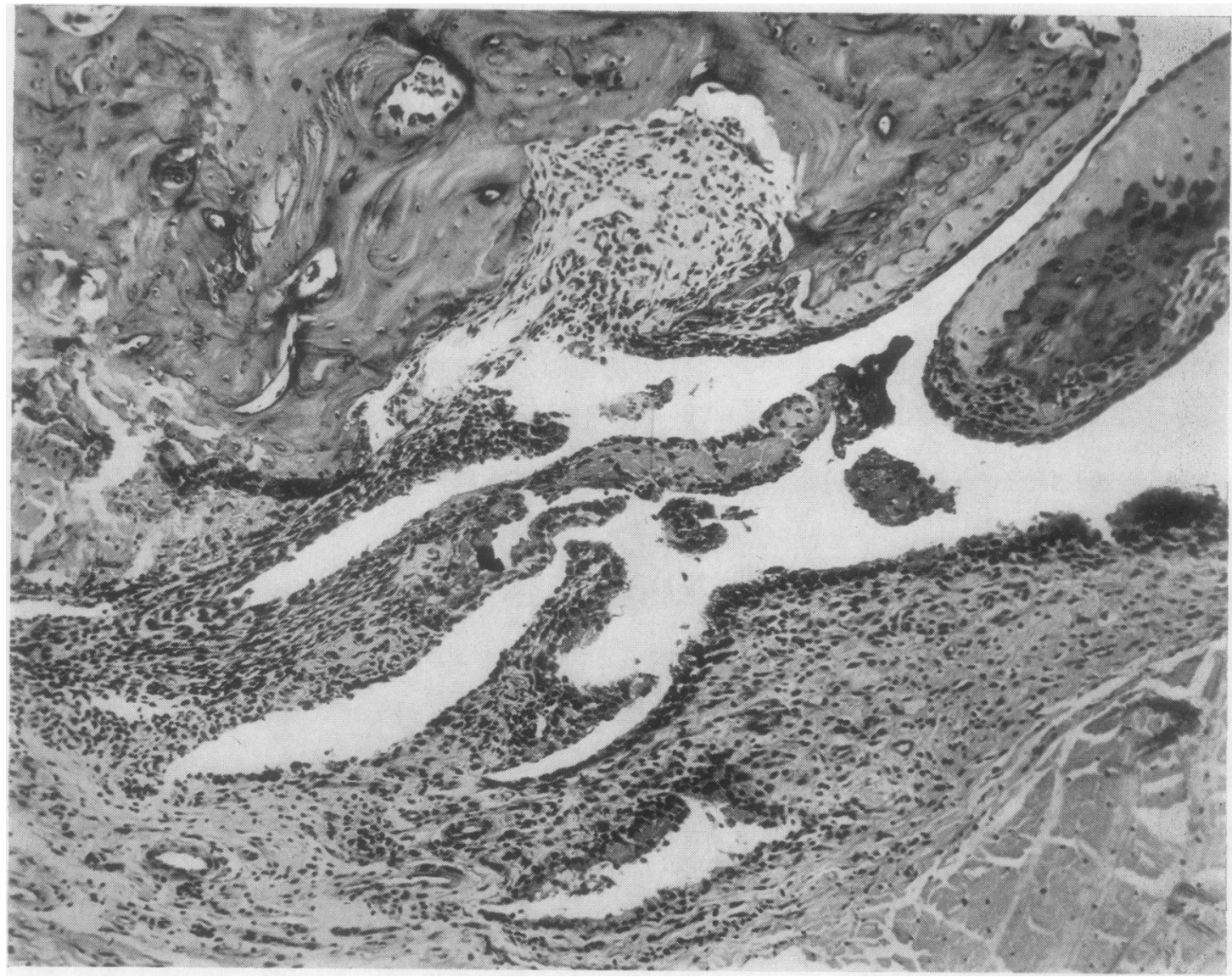

Fig. 1.- Joint of rat with homologous disease demonstrating synovitis. An intense mononuclear inflammatory reaction is associated with proliferation of synovial cells. $\times 115$.

Appropriate control animals showed none of these changes.

Cultures of 25 joints and 22 hearts for pyogenic and pleuro-pneumonia-like organisms (PPLO) by Dr. John Ward of the University of Utah have been negative. He used six different media, and in addition, inoculated egg embryos.

Skin Changes.-The skin was the site of a number of interesting findings. In experiments in which autografts and homografts were applied simultaneously one day after the last injection of homologous lymphoid cells, we were surprised to observe that eight tolerant recipients, who accepted homografts, rejected their simultaneously placed autografts (Fig. 3, opposite). Rejection of autografts was also observed in six other animals who had accepted a homograft within a 6-week period. This observa- tion provides convincing evidence of an immune response directed against antigens in the skin of animals with homologous disease.

Spontaneous skin changes were frequent. Alopecia, purpura, an acute erythematosus dermatitis, and a more chronic type of dermatitis were observed.

The acute spontaneous dermatitis, which was characterized by hyperkeratosis, follicular plugging, hydropic degeneration of epithelial cells, and infiltration of the dermis, was not unlike the skin lesion seen in systemic lupus erythematosus. Its histological appearance also resembled that of autografts undergoing the more acute variety of autograft rejection seen in these animals.

In some animals, the dermatitis was, as mentioned, more chronic, being characterized by alopecia and 


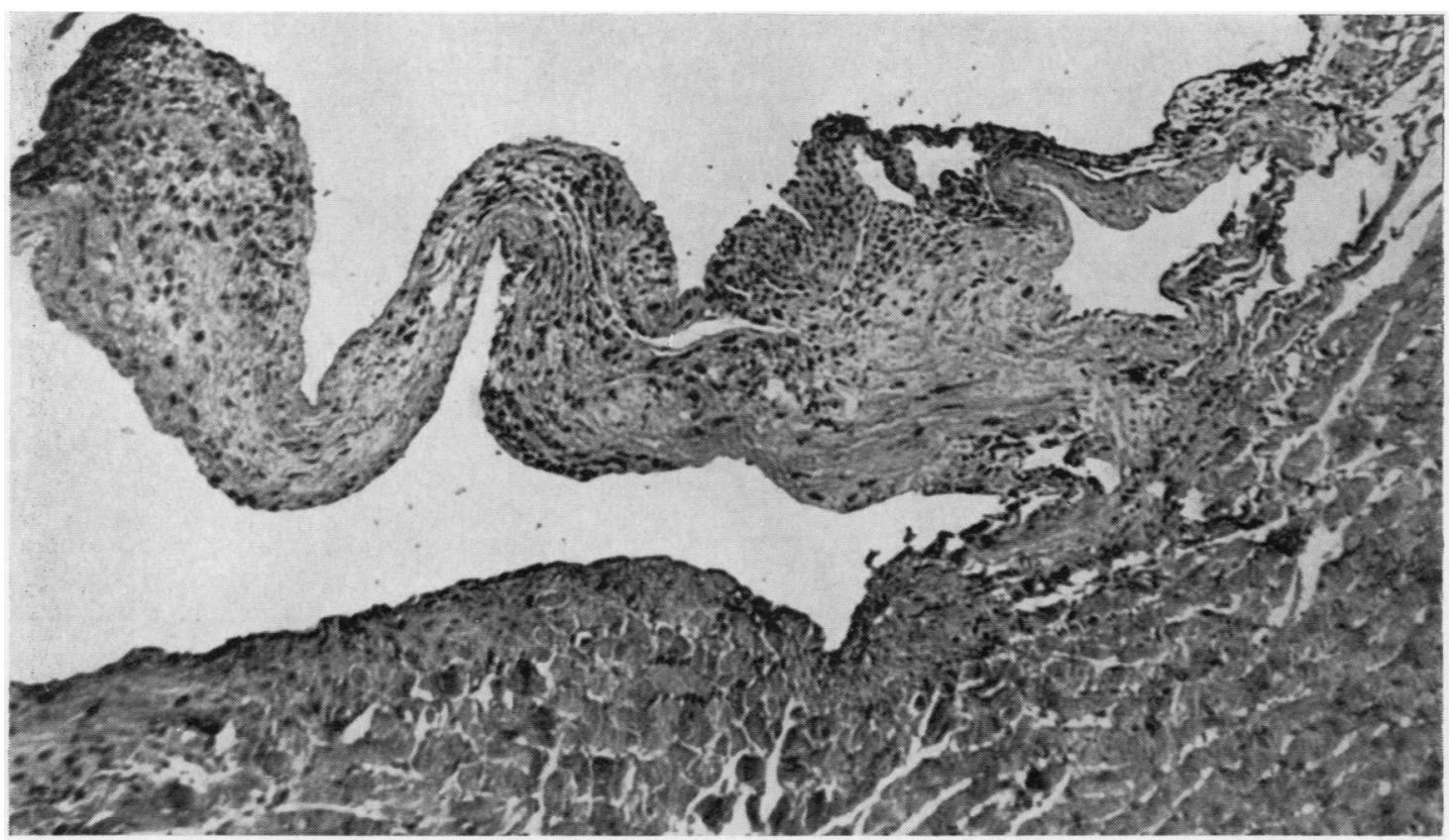

Fig. 2.-Mitral valve in rat with homologous disease, showing mononuclear inflammatory reaction and fibrosis. $\times 100$.

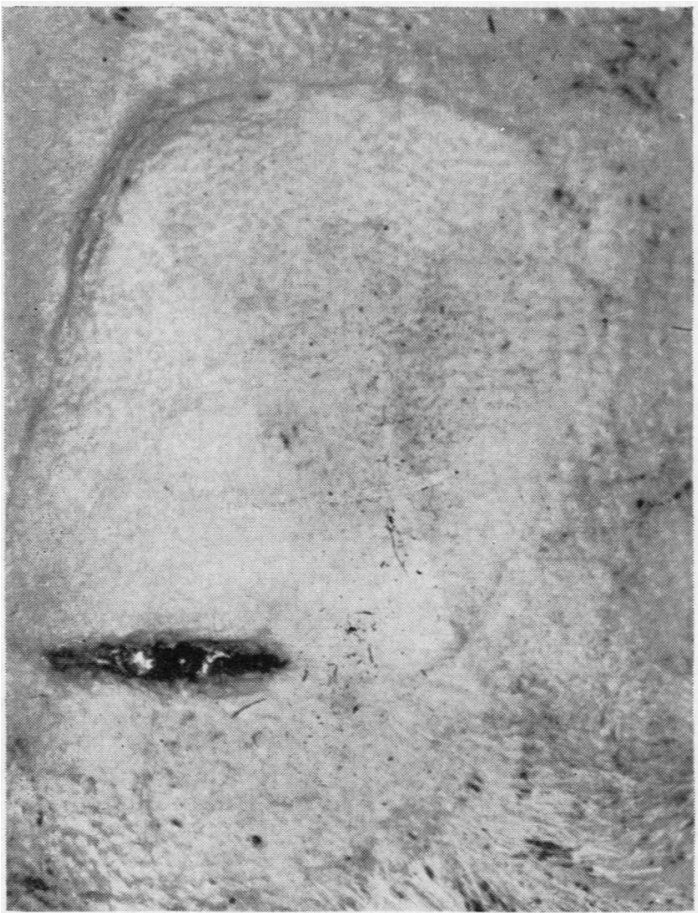

(A)

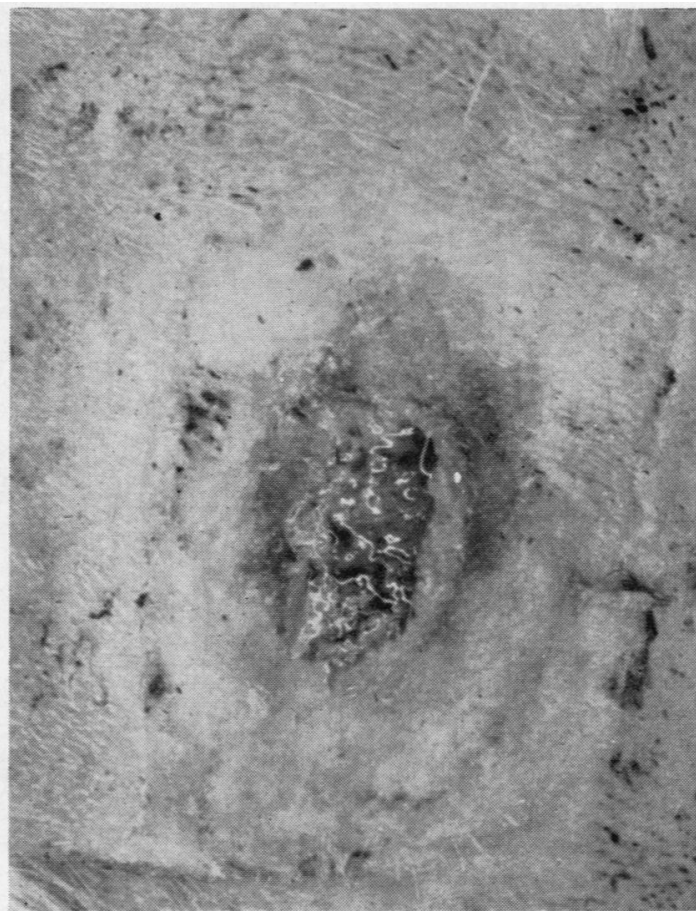

(B)

Fig. 3. - Simultaneous donor strain homograft (A) and autograft (B) in rat with homologous disease at 11 days. The homograft (A) is being accepted and the autograft (B) rejected. 
thickening of the skin. Histologically, there was marked thinning of the epidermis, thickening and collagenization of the dermis, and disappearance of the skin appendages. Autografts undergoing a prolonged type of rejection, which took place over a period of 40 days or more, showed a similar type of atrophy and fibrosis microscopically. The histological appearance of this chronic type of dermatitis was not unlike that seen in human scleroderma.

Thus, there appeared to be a parallel (Fig. 4),

\section{Acute Autograft Rejection \\ Acute Dermatitis \\ Lupus Erythematosus? \\ Chronic Autograft Rejection \\ Chronic Dermatitis \\ Scleroderma?}

Fig. 4.

between an immunologically-induced relatively acute type of autograft rejection and a more acute type of dermatitis; and also between an immunologicallyinduced more chronic type of autograft rejection and a more chronic type of dermatitis - the more acute type of spontaneous lesion being reminiscent of lupus erythematosus and the more chronic of scleroderma. This would suggest that the skin lesions of the latter two diseases also have an immunologic basis.

Further evidence for the immunologic basis of the skin lesions was seen in the interesting observation that when dermatitis occurred spontaneously in the region of a homograft, the homograft skin was spared. This indicates that the antigens of the host skin and not of the donor skin were the target of the immune response-thus providing evidence that the skin lesions had immunologic specificity.

The evidence for the immunologic basis of the skin lesions in homologous disease may, therefore, be summarized as follows:

(1) Autografts are rejected.

(2) The histological appearance of the spontaneous skin lesions resembles that of the autografts undergoing rejection.

(3) The spontaneous dermatitis is specific for host skin.

Kidney.-The most consistent change in this organ was an interstitial mononuclear inflammatory reaction, usually perivascular in location, which was observed in 19 out of 56 animals. The glomeruli were not significantly involved. This interstitial and perivascular response resembled that seen in the rejection of kidney transplants. The absence of glomerular and basement membrane changes argues against a significant role of serum antibody in the kidney changes, and emphasizes the predominant role of the cellular immune response in the lesion. The cellular response is presumably the predominant type of immune response underlying most of the tissue changes of homologous disease. Consistent with this was the finding that the titre of serum complement in these animals was raised rather than depressed.

Thus, homologous disease is characterized by the following changes: weight loss, pancytopenia, skin lesions, rejection of autografts, migratory polyarthritis, myocarditis, valvulitis, and interstitial lesions in the kidney. These diffuse, multi-system changes appear to be an obligatory consequence of the growth of immunologically-competent foreign cells in an otherwise normal host. If these observations are taken at face value, the development of sufficient numbers of abnormal, immunologically-competent autologous cells in an otherwise normal host should be sufficient, without the intervention of extrinsic agents, to produce a multi-system type of inflammatory disease.

Although the available evidence indicates that the skin lesions of homologous disease are a consequence of a homograft reaction, one cannot rule out the possibility that antigens other than transplantation antigens are involved in the joint and heart lesions described. The animal with homologous disease may have a decreased resistance to infection, although this has thus far, surprisingly, been denied (Billingham, Defendi, Silvers, and Steinmuller, 1962; Simonsen, 1962). Early in the disease, its immunologically-competent cells are, in all likelihood, preempted (Blaese, Martinez, and Good, 1964) by the large number of host antigens which are under attack in the graft-versus-host reaction; and later, there is marked atrophy of the lymphatic tissue. Although ordinary pathogens and PPLO have not been cultured from the joints and heart directly, it is not possible to rule out the effects of antigens derived from foci in other organs. Joint (Collins and Goldie, 1940) and heart (Murphy and Swift, 1949) lesions due to bacterial hypersensitivity have been previously described in other circumstances.

The possibility that a virus is the cause of the joint and heart lesions also merits consideration, since multi-system, mononuclear inflammatory disease due to virus infection has been demonstrated in the mouse (Hotchin, 1962). If, as appears possible in homologous disease, the capacity for delayed hypersensitivity is retained, the host could become a candidate for a diffuse, virus-induced, but immunologically mediated, inflammatory disease in which delayed hypersensitivity to a virus related antigen 
plays a prominent role. This type of condition has been postulated by Hotchin in the adult mouse with lymphocytic choriomeningitis (LCM). In the condition described as "late disease" in the LCM infected adult mouse, loss of neonatal tolerance to the latent LCM virus is followed by a diffuse inflammatory disease which appears to be immunologically mediated.

Whether the host provides the antigens directly or an infectious agent instead, an immune response, which produces a familiar pattern of infiltration in a number of organs, appears to lie at the basis of the inflammatory changes of homologous disease. Since our model for human disease leaves us for the time being with the same perplexities that exist with regard to the human prototype itself, it may be a valid model indeed.

\section{Electron Microscope Studies of the Rheumatoid Synovial Membrane}

Having discussed the problems raised by an immunologically induced multi-system disease in the rat, I should like now to turn to the rheumatoid synovial membrane and to examine the anatomical basis for a possible immune response in this tissue.

The joint, according to Bauer, Ropes, and Waine
(1940), is a connective tissue space. The synovial membrane itself is a loosely textured, vascular connective tissue, the surface of which is lined by a characteristic layer of lining cells. Lymphatic vessels form a fine plexus beneath the synovial lining. Proteins are believed to enter the joint space via the capillaries and to leave by the lymphatic drainage (Bauer, Short, and Bennett, 1933).

The rheumatoid synovial membrane consists essentially of two parts-a swollen and proliferated lining layer resting upon a vascular and oedematous stroma densely infiltrated with lymphocytes, macrophages, and plasma cells. Electron microscopy has shown that the lining layer is made up of the same types of cells as are found in the lining of the normal synovial membrane (Barland, Novikoff, and Hamerman, 1962). The electron microscope data shown below were obtained by Dr. Walter Norton of our unit in his studies of the rheumatoid synovial membrane. Fig. 5 shows the cell types of the lining layer-a phagocytic type A cell which has the appearance and properties of a macrophage, and next to it a cell containing larger amounts of ergastoplasm and fewer vacuoles, the so-called type B cell. The latter is presumably engaged in the synthesis of hyaluronic acid.

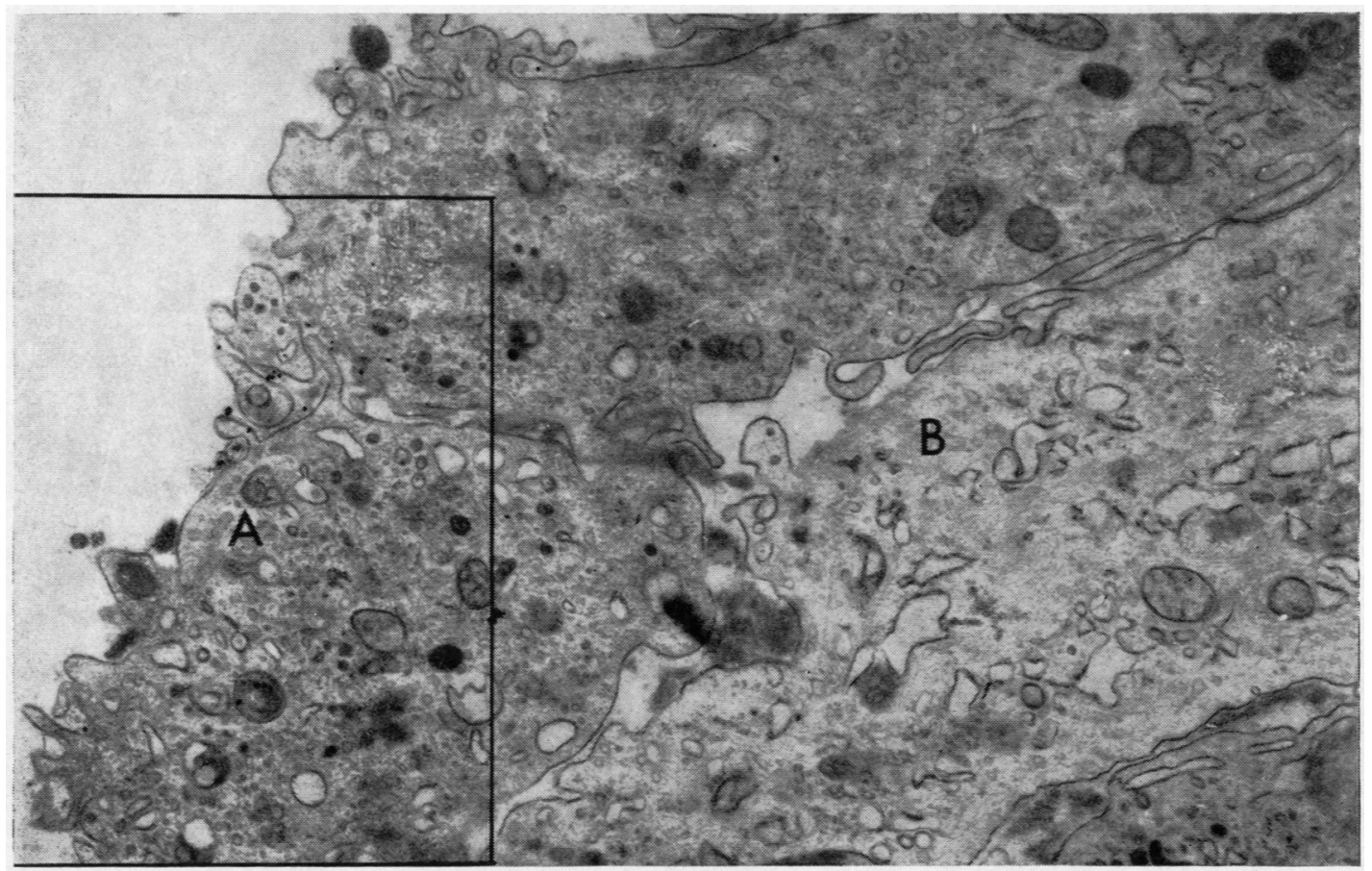

Fig. 5.-Electron micrograph of lining cells of rheumatoid synovial membrane: (A) Phagocytic (Type A) cell; (B) Type B cell containing ergastoplasm. $\times 13,500$. 
Fig. 6 presents an enlargement of the A cell showing intra-articularly injected colloidal gold particles concentrated in the vacuoles.

Below the lining layer, and usually separated from it by a narrow band of fibrous tissue, are the collections of mononuclear inflammatory cells, made up of lymphocytes, plasma cells, and macrophages (Fig. 7, opposite). These mononuclear cells appear to be limited to the deeper, vascularized areas of the synovial membrane, and do not infiltrate the lining layer. This is shown schematicallyinFig. 8 (opposite).

Immunologic Aspects of the Rheumatoid Synovial Reaction.--The lack of infiltration of the lining layer, as noted above, added to the fact that in the active rheumatoid synovium the lining cells showed no convincing degenerative or "invasive destructive" changes, suggests that the synovial cells themselves are not the target of the inflammatory process. The evidence seems strong, nevertheless, that the rheumatoid synovial infiltrate is a consequence of an immunologic reaction:

(1) Fluorescent staining of the inflamed membrane has demonstrated the presence of 7S and 19S gamma globulin.

(2) Serum complement has been shown to be fixed in this membrane, especially in areas where $7 \mathrm{~S}$ gamma globulin is deposited (Rodman, Williams, Bilka, and Müller-Eberhard, 1964).

(3) The synthesis of rheumatoid factor in the synovial granuloma, as shown by fluorescent staining

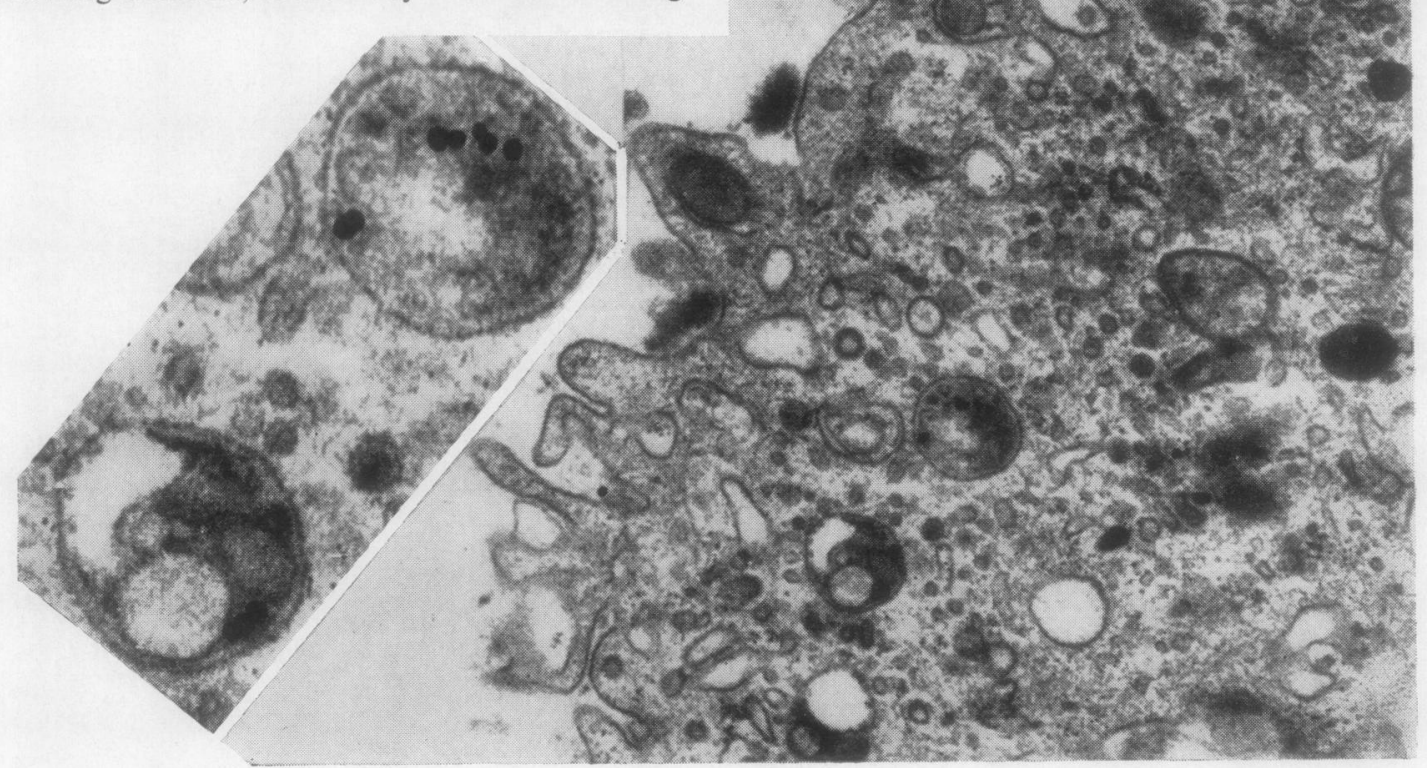

Fig. 6.-Higher magnification of Type A cell in Fig. 5, showing intra-articularly-injected colloidal gold particles in vacuoles. $\times 27,000$. [Inset higher magnification of vacuoles. $\times 100,000$.
(Mellors, Heimer, Corcos, and Korngold, 1959), is evidence that plasma cells are being stimulated, possibly by aggregated gamma globulin, but more likely by gamma globulin in antigen-antibody combination. This would indicate that antigen is present within the involved synovial membrane.

(4) Pekin and Zvaifler (1964) have recently shown that the complement level is lowered in the rheumatoid synovial effusion compared to the total protein and white cell count. This is in contrast to the raised complement levels in the blood in rheumatoid arthritis, and in the synovial fluid in gout and Reiter's disease. The latter evidence suggests that

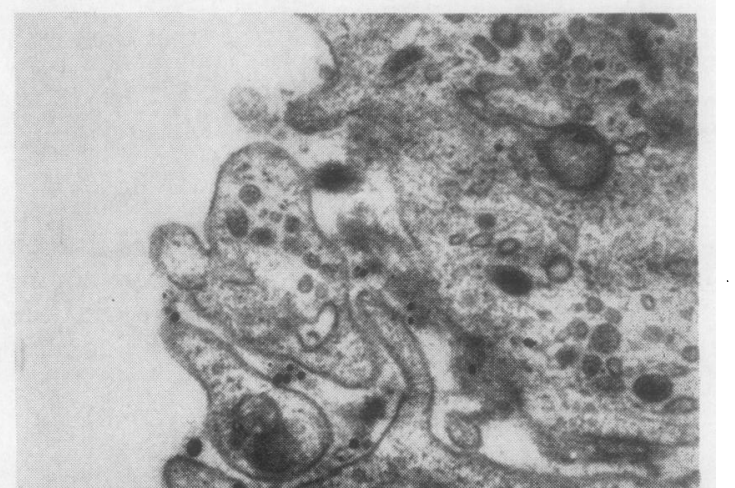




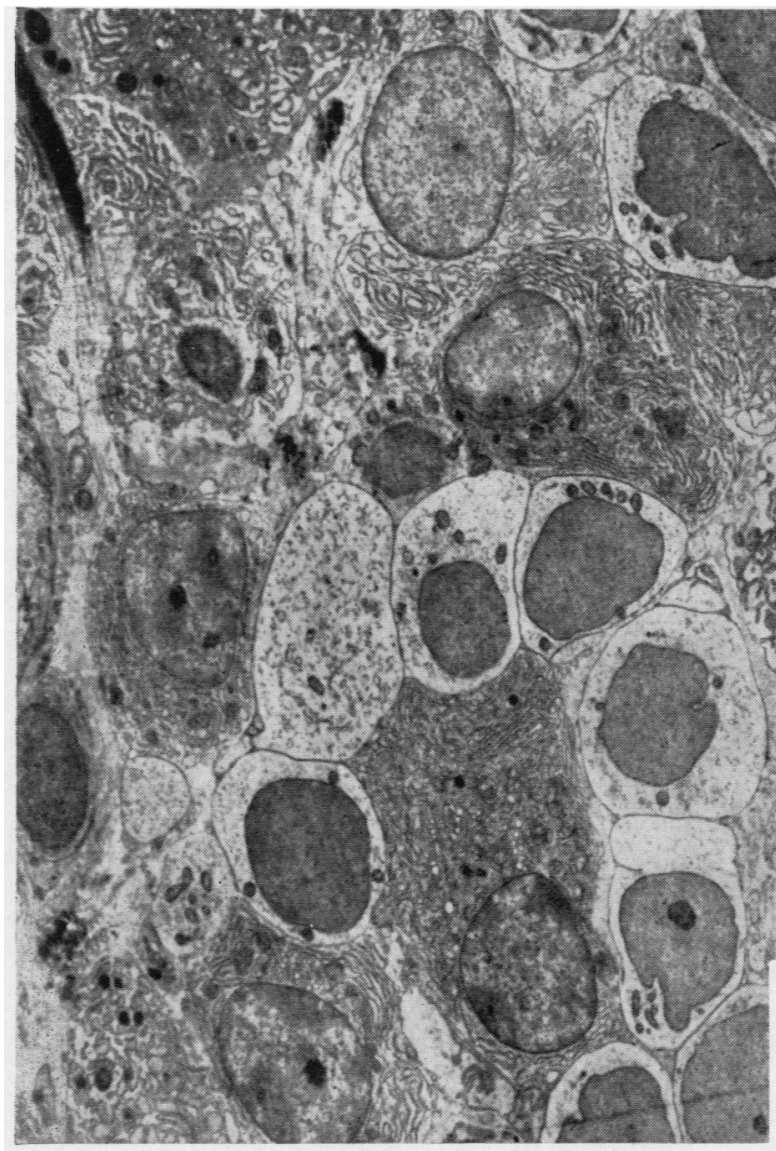

Fig. 7.-Mononuclear inflammatory cells in deep layer of rheumatoid synovial membrane, showing lymphocytes and plasma cells. $\times 2,600$.

Fig. 8.-Drawing of rheumatoid synovial membrane, showing proliferating lining layer composed of Type A cells (A), Type B cells (B), and undifferentiated cells (U). The lining layer is free of inflammatory cells and is separated from these by a layer of collagenous tissue.

one or more antigen-antibody complexes are present within or in contact with the synovial fluid itself (Fig. 9, overleaf).

A rather remarkable feature of the synovial inflammatory reaction is the well-known dissociation between the mononuclear response in the synovial tissue and the neutrophilic exudation in the synovial fluid. The simultaneous occurrence of these two phenomena seems, in part, to be a consequence of the anatomy of the joint (Fig. 9, overleaf). In this structure, the synovial membrane, a loose and vascular connective tissue, presumably capable of absorbing antigen and responding to it with a cellular immune response, is in contact with a pool of extracellular fluid (the synovial fluid), which is available to
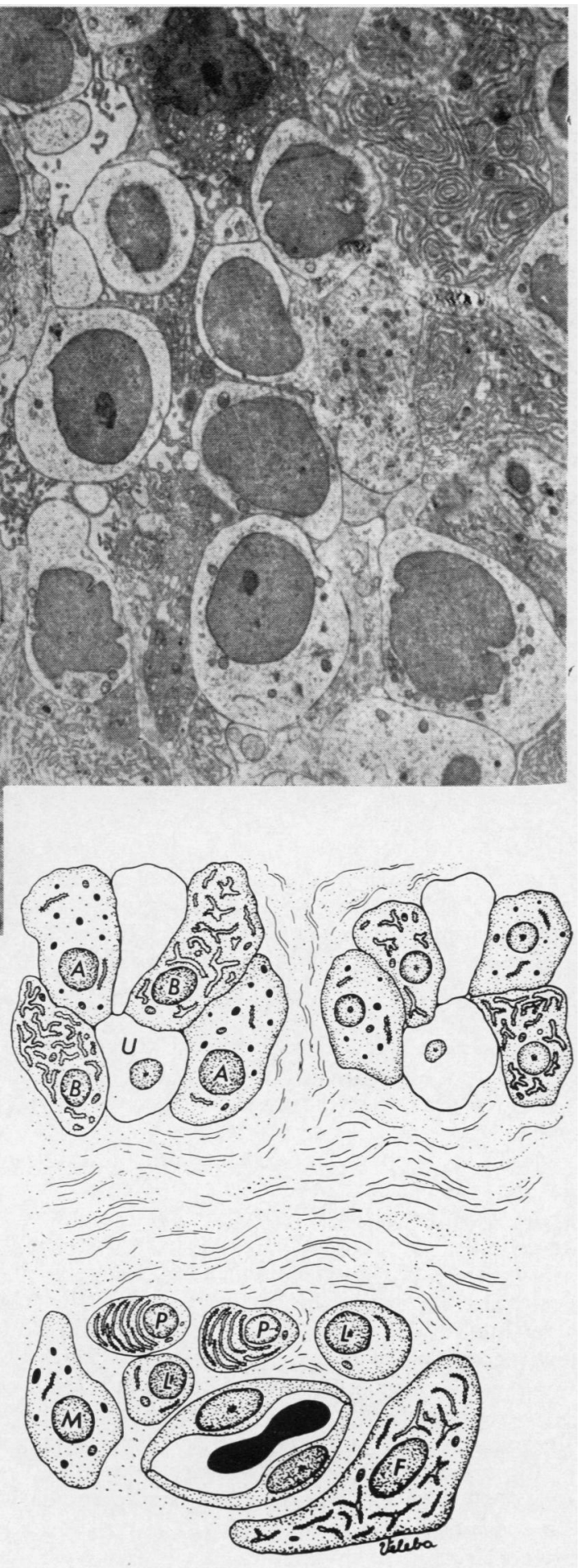


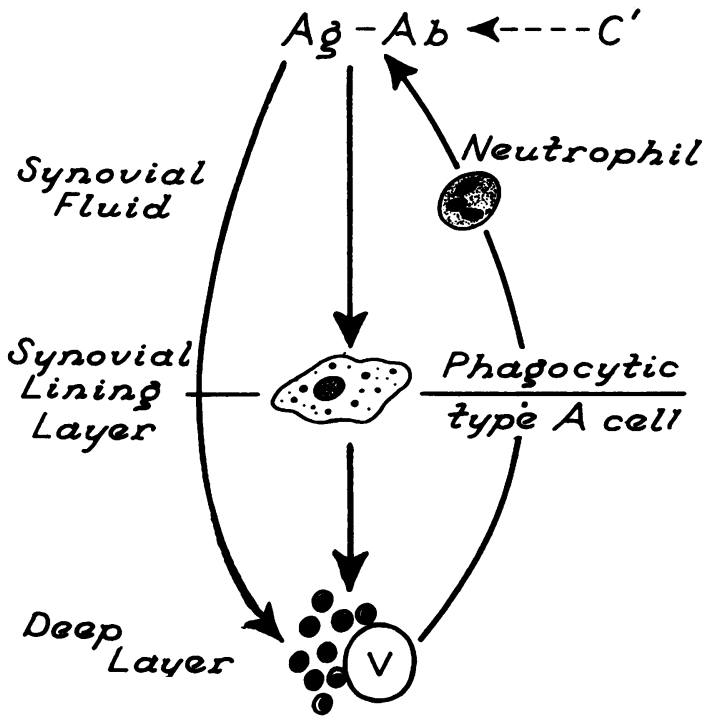

Fig. 9.-Schematic diagram of synovial membrane and synovial fluid interface. Synovial fluid contains neutrophils arising in capillary (V), and has lowered serum complement. Synovial membrane contains phagocytic lining cells and mononuclear infiltrate in deeper layer (see text).

collect neutrophils. While lymphocytic proliferation associated with the immune response appears to go on in the deeper vascularized portion of the synovial membrane, the neutrophils are attracted, through some mechanism as yet unexplained, to the synovial fluid. This may be a consequence merely of greater mobility, a factor which may be rendered more critical in the inflamed synovium by the greater distance of the vascular bed from the synovial space.

One cannot help being impressed, to begin with, with the possibility that the synovial membrane is a site at which primary immunization can occur, much as in a lymph node, since it is richly equipped with a lining layer of phagocytic cells capable of taking up antigen, and with the vascular supply and connective tissue space necessary for the mobilization and proliferation of lymphocytes. Thus, if an antigen, or antigen-antibody complex, were available in the synovial fluid or in the interstitial space of the synovium itself, the type A cell might well absorb it and place it in the appropriate assembly line for the initiation and maintenance of a cellular immune response in a manner similar to that postulated by Nossal, Ada, and Austin (1964) for the macrophages of the primary follicle of the lymph node. In this sense, the rheumatoid synovial membrane would have something in common with a lymph node undergoing primary immunization.
That antigen should also be able to find its way, if necessary, to the deeper layers of the synovial membrane, where it could directly stimulate the proliferation of sensitized cells in the synovial infiltrate, is suggested by the observation (Fig. 10, opposite) that intra-articularly injected colloidal gold particles may pass between the lining cells of the rheumatoid synovial membrane. It would appear, therefore (as previously stated by Bauer and others, 1940), that the intercellular space of the synovial membrane represents a functional part of the synovial cavity. Exercise of the joint may well be a factor in movement of antigen toward the deeper layers, as indicated by the well-known observation that paralysis (Thompson and Bywaters, 1962) and splinting may diminish inflammation in rheumatoid arthritis. Antigen supplied by synovial capillaries could, of course, react with perivascular cells directly.

Dumonde and Glynn (1962) have examined the effects of antigen placed in the synovial cavity. In a series of interesting experiments, they sensitized rabbits to autologous as well as heterologous fibrin, and then injected these agents into the joint with the production of a chronic arthritis which resembled rheumatoid arthritis histologically. Their work indicates that antigen - even autoantigen-deposited in the joint may bring about a chronic arthritis, at least in the sensitized individual.

If there is an antigen in the synovial space of the patient with rheumatoid arthritis, what kind of antigen may it be? An autoantigen, or an exogenous antigen, such as a virus or a pleuropneumonialike organism? With regard to possible autoantigens, our electron microscopic observations, demonstrating the integrity of the rheumatoid synovial lining cell layer, suggest that the antigen is not bound to the synovial cell. This would not necessarily rule out the possibility that an antigen is released by the synovial cells. It is known from the work of Mannick, Graziani, and Egdahl (1964) that explanted spleen cells in tissue culture may release transplantation antigen into the surrounding culture medium. Since the synovial lining cells have, to some extent, properties of reticulo-endothelial cells, this possibility must be considered. With regard to other possible autoantigens, the antigen could, of course, be an autologous protein continuously available in the synovial fluid, as suggested by the work of Dumonde and Glynn.

The antigen could, as mentioned, also be exogenous, as for instance, a pleuropneumonia-like organism (PPLO) or a latent virus. PPLO have been recently isolated from rheumatoid joints by Bartholomew and Himes (1964) using a tissue culture 


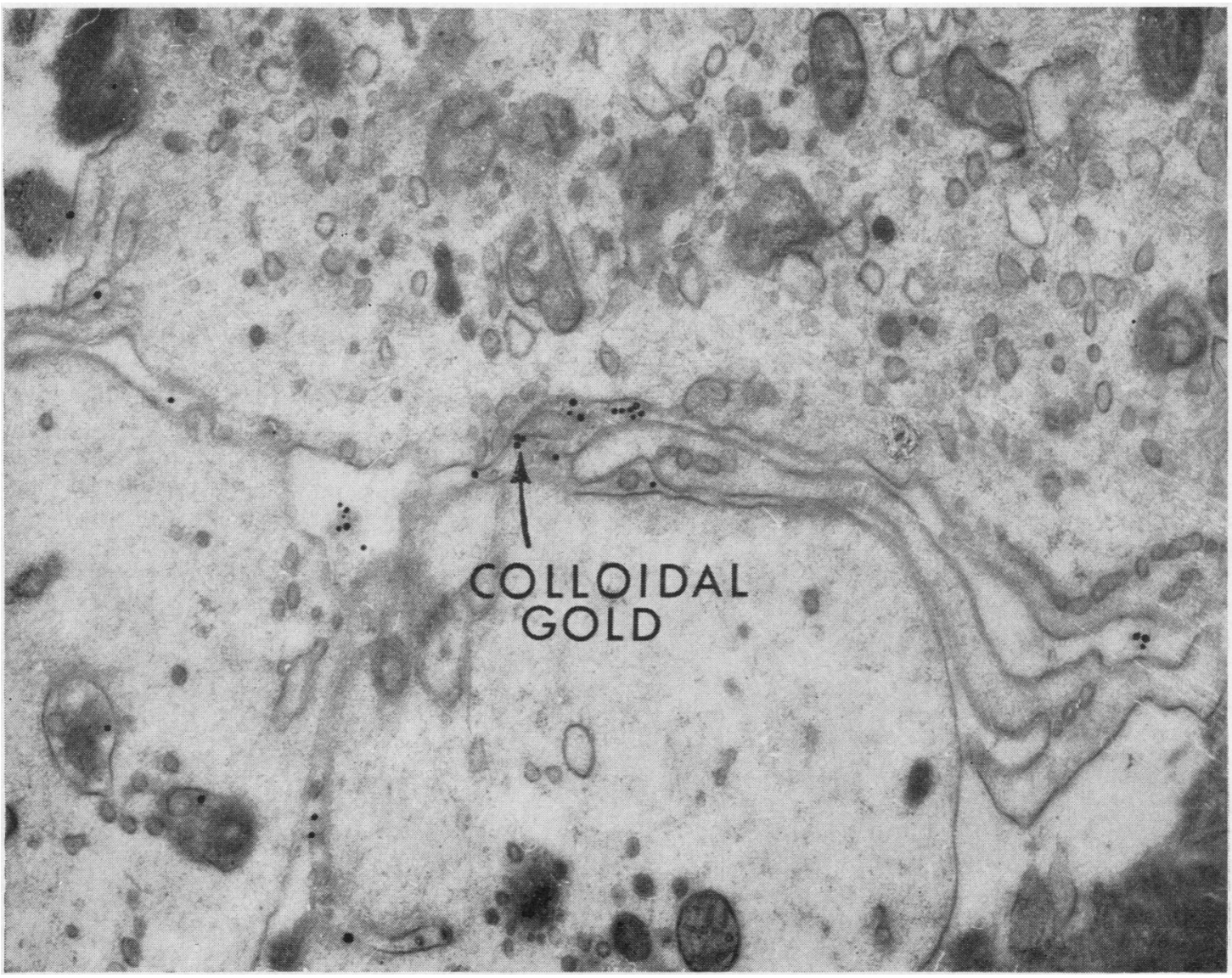

Fig. 10.-Electron micrograph, showing intra-articularly-injected colloidal gold particles penetrating between lining cells of rheumatoid synovial membrane. $\times 27,500$.

technique. With respect to the possibility of a latent virus, recent studies have shown that viruses such as Adenovirus Type 12 and SV-40 may direct the synthesis of virus-like antigens in tumours by changing the genetic apparatus of the tumour cells (Huebner, Rowe, Turner, and Lane, 1963), and that polyoma virus may bring about the synthesis of new, abnormal host-related antigens to which the host becomes sensitive and develops delayed hypersensitivity. The latter process could, of course, lead to autoimmune reactions (Habel, 1963). Interesting, also, is the "late disease" of mice rendered tolerant to LCM virus neonatally (Hotchin, 1962). As these mice age, they may lose tolerance and develop a diffuse multi-system disease which has been thought by Hotchin to represent a delayed hypersensitivity state to virus-induced antigens in transformed host cells. Thus, a number of animal viruses appear to be capable of leading to the development of antigens capable of inducing an immune response in the host.

\section{Autoantibodies in the Patient}

Having considered a number of aspects of a possible immune mechanism for the development of the rheumatoid synovial inflammatory reaction, I would now like to turn to some aspects of autoimmunity in the whole patient. Let us consider some experiments carried out by Dr. John Baum which will perhaps cast some light from the point of view of the autoantibodies in the serum of patients with connective tissue disease.

It is well established that most, though not all, antibodies appear in the serum in two phases. First, a heavy or $19 \mathrm{~S}$ antibody appears; after a week or so, a light or $7 \mathrm{~S}$ antibody begins to be present while the $19 \mathrm{~S}$ antibody tends to disappear. Dr. 
Baum has examined the distribution of the heavy and light forms of two autoantibodies, the antinuclear factor (ANF) and anti-thyroglobulin antibody, in patients with rheumatoid arthritis, systemic lupus erythematosus (SLE), and other diseases. Similar studies in regard to the ANF have been carried out by Barnett, Condemi, Leddy, and Vaughan (1964).

7S and 19S ANF were separated by DEAE cellulose chromatography. It was found (Table I) that the 7S ANF was present in 100 per cent. of SLE patients and in only 37 per cent. of rheumatoid patients; on the other hand, the 19S ANF was present in 100 per cent. of rheumatoid patients and only 29 per cent. of SLE patients. The finding of 7S ANF alone was characteristic of 71 per cent. of SLE patients and none of the rheumatoid patients; the finding of $19 \mathrm{~S}$ ANF alone was characteristic of 63 per cent. of rheumatoid patients and none of the SLE patients. We see here a definite propensity on the part of the rheumatoid patients to elaborate 19S ANF, and on the part of the SLE patients to elaborate 7S ANF.

TABLE I

7S AND 19S ANTINUCLEAR FACTOR (ANF) IN RHEUMATOID ARTHRITIS AND SYSTEMIC LUPUS ERYTHEMATOSUS (SLE)

\begin{tabular}{c|c|c|c|c}
\hline \multirow{2}{*}{$\begin{array}{c}\text { Type of } \\
\text { ANF }\end{array}$} & \multicolumn{2}{|c|}{ Rheumatoid Arthritis } & \multicolumn{2}{|c}{ SLE } \\
\hline & No. & Per cent. & No. & Per cent. \\
\hline $7 \mathrm{~S}$ & 0 & 0 & 12 & 71 \\
\hline $7 \mathrm{~S}+19 \mathrm{~S}$ & 7 & 37 & 5 & 29 \\
\hline $19 \mathrm{~S}$ & 12 & 63 & 0 & 0 \\
\hline
\end{tabular}

In the case of anti-thyroglobulin antibody, 21 patients with SLE out of a total of 35 tested showed measurable amounts of antibody. The titres of the separated antibody containing fractions (Table II) were markedly greater than those of the rheumatoid patients, and the major component in seventeen of the twenty positive individuals was $7 \mathrm{~S}$ antibody. In 21 patients with definite rheumatoid arthritis who had thyroglobulin antibody, on the other hand, the

TABLE II

DISTRIBUTION OF MAJOR COMPONENTS OF ANTI-THYROGLOBULIN ANTIBODY AND TITRE IN RHEUMATOID ARTHRITIS AND SYSTEMIC LUPUS ERYTHEMATOSUS (SLE)

\begin{tabular}{c|c|c|c|c}
\hline Diagnosis & $\begin{array}{c}\text { No. of } \\
\text { Patients }\end{array}$ & $\begin{array}{c}\text { No. with } \\
\text { Titre } \\
1: 320\end{array}$ & Major Component* \\
\hline $\begin{array}{c}\text { Rheumatoid } \\
\text { Arthritis }\end{array}$ & 21 & 2 & $7 \mathrm{~S}$ & $19 \mathrm{~S}$ \\
\hline SLE & 20 & 14 & 17 & 16 \\
\hline * $=<\cdot 01$.
\end{tabular}

antibody titre was generally low and predominantly in the 19S form. Thus, for this antibody, too, SLE patients tended to elaborate the $7 \mathrm{~S}$ form and rheumatoid patients the 19S; and the 7S antibody was present in high titre and the $19 \mathrm{~S}$ generally in low titre.

Since thyroglobulin antibody is known to occur in aged persons (Goodman, Rosenblatt, Gottlieb, Miller, and Chen, 1963) and in patients with pernicious anaemia (Doniach, Roitt, and Taylor, 1963), these two groups were examined, as well as a group of patients with pulmonary tuberculosis. Thirteen of 42 aged persons had antibodies; in twelve, the picture resembled that in rheumatoid arthritis, i.e. low titres of mainly 19S antibody were found. (In one, the antibody was intermediate in size.) A similar picture was seen in nine patients with pernicious anaemia who had antibody; seven of the nine had 19S antibody alone, and in low titre. Similar findings were also obtained in 44 patients with pulmonary tuberculosis; nine had antibody, all in low titre and in the $19 \mathrm{~S}$ form.

It seems clear from these findings that the patient with SLE tends to produce the two autoantibodies studied in the 7S form and, at least in the case of the thyroid antibody, in high titre; the rheumatoid patient, on the other hand, tends to produce them mainly in the 19S form, and at least in the case of thyroid antibody, in low titre. What is the significance of this difference?

There is reason to believe that $19 \mathrm{~S}$ antibody is a product of primary immunization, and is probably made by a different mechanism from $7 \mathrm{~S}$ antibody, which is generally characteristic of the secondary immune response. In the primary response, antigen is thought to be taken up initially in macrophages which then, through some as yet unidentified agent, stimulate the lymphocyte to proliferate, differentiate, and produce specific antibody (Fishman, 1961; Fishman and Adler, 1963). The secondary response, in contrast, appears to involve "memory cells", probably small lymphocytes, which can, presumably, be stimulated more directly by antigen to proliferate and produce 7S antibody (Dutton and Eady, 1964).

The greater tendency of patients with SLE to produce 7S ANF and anti-thyroid antibody and the higher titre of the latter in this disease indicate a vigorous autoantibody response in SLE as contrasted with rheumatoid arthritis. This is consistent with the large number of autoantibodies found in SLE (Holman, 1960), and with the decreased level of serum complement (Townes, Stewart, and Osler, 1962) and the occurrence of renal disease with basemembrane deposits in this disease. These phenomena may well be a consequence, not only of an 
increased concentration of $7 \mathrm{~S}$ serum autoantibody, but also of the recognized capacity of 7S antibody, in contrast to $19 \mathrm{~S}$, to form classical antigen-antibody complexes, which are capable of fixing complement, producing vascular lesions, and leading to basement membrane thickening in the kidney.

The rheumatoid patient, in contrast, appears to retain to a considerable degree a persistent primary (19S) response in regard to the two autoantibodies studied. His serum level of anti-thyroid antibody, though low, was comparable to that of the aged persons and of the patients with pernicious anaemia and tuberculosis. Thus, the SLE group appears to be characterized by a more active response than the other groups studied. Is it a question of the magnitude of the stimulus-potent in SLE, and small in rheumatoid arthritis and the other patient groups? Or is there a group of constitutionally vigorous responders who, on meeting the same immunologic stimuli as the rheumatoid patient, respond more actively and as a consequence develop the changes of SLE, while ordinary responders develop rheumatoid arthritis? The similarity of behaviour exhibited by patients with SLE with respect to a number of autoantibodies suggests that they are not reacting to increased stimulation by individual antigens, but are, in fact, vigorous responders.

\section{Summary}

(1) If an experimental animal is created in which immunologically-competent cells are obliged to react in vivo with the antigens of their host, as in the animal with homologous disease, inflammatory lesions develop. Lesions observed in the joints and heart appear to be the result of a reaction between foreign cell and host antigen; but the possibility that they are a consequence of a hypersensitivity reaction to an infectious agent remains to be considered. This unresolved question applies also to the consideration of human connective tissue disease, for which homologous disease may be a model.

(2) The synovial membrane with its layer of phagocytic lining cells may be potentially capable of functioning as a site of primary immunization, leading to infiltration of its deeper layers with mononuclear cells as a consequence of uptake of antigen from the synovial space. In the presence of established hypersensitivity, it could also be the site of proliferation of sensitized cells. In these respects, the synovial membrane would have features in common with a lymph node; and, like the lymph node, it could be maintained in a chronically active state in a localized anatomical site by the continuous availability of antigen to that site.
(3) Evidence of direct interaction between synovial cells and lymphocytes in the rheumatoid synovial membrane has not been observed in electron microscopic studies. Available information suggests the existence of an antigen in the synovial fluid or in contact with it. This antigen may be an autologous constituent, but it is not possible to rule out a latent infectious agent in this role.

(4) Autoantibody formation in rheumatoid arthritis tends to be stalled, at least in part, at the level of the primary or $19 \mathrm{~S}$ response. This is not inconsistent with the histological character of the rheumatoid inflammatory process and its tendency to remain localized. In contrast, the patient with SLE tends to produce a number of serum autoantibodies; these appear to be present in relatively high titre and to undergo a relatively marked transition to the 7S form. The clinical and serological features of SLE are, furthermore, consistent with the presence of increased amounts of $7 \mathrm{~S}$ autoantibody in the blood. Differences in serum autoantibody formation between rheumatoid arthritis and systemic lupus erythematosus, it is suggested, represent a variation in host response.

As I end this lecture, may I conclude on a note of fancy, if you will. It has occurred to me that, among the many explorers of unsolved puzzles in medicine, we rheumatologists have been granted a favoured position. Probably, in a mood of indulgence for our obvious deficiencies, Nature has, from her many gauntlets, thrown us her very simplest-a thin and fragile sliver of connective tissue. "Take this frail membrane", she seems to say, "and tell me, if you can, why from time to time, it fills with lymphocytes. No more, no less. And if you do, I will tell you in return many secrets of faraway tissues in distant organs that you have never dreamed of." I suggest we owe this lady, who, if nothing else, has always kept her bargain, a special vote of thanks.

\section{REFERENCES}

Barland, P., Novikoff, A. B., and Hamerman, D. (1962). J. Cell Biol., 14, 207.

Barnett, E. V., Condemi, J. J., Leddy, J. P., and Vaughan, J. H. (1964). J. clin. Invest., 43, 1104.

Bartholomew, L. E., and Himes, J. (1964). Arthr. and Rheum., 7, 291.

Bauer, W., Ropes, M. W., and Waine, H. (1940). Physiol. Rev., 20, 272.

Short, C. L., and Bennett, G. A. (1933). J. exp. Med., 57, 419.

Billingham, R. E., Defendi, V., Silvers, W. K., and Steinmuller, D. (1962). J.nat. Cancer Inst., 28, 365. 
Blaese, R. M., Martinez, C., and Good, R. A. (1964). J. exp. Med., 119, 211.

Collins, D. H., and Goldie, W. (1940). J. Path. Bact., 50, 323.

Doniach, D., Roitt, I. M., and Taylor, K. B. (1963). Brit. med. J., 1, 1374.

Dumonde, D. C., and Glynn, L. E. (1962). Brit. J. exp. Path., 43, 373.

Dutton, R. W., and Eady, J. D. (1964). Immunology, 7, 40.

Fishman, M. (1961). J. exp. Med., 114, 837.

and Adler, F. L. (1963). Ibid., 117, 595.

Goodman, M., Rosenblatt, M., Gottlieb, J. S., Miller, J., andChen,C.H.(1963). Arch.gen.Psychiat.,8,518.

Habel, K. (1963). Ann. Rev. Microbiol., 17, 167.

Holman, H. (1960). J. Pediat., 56, 109.

Hotchin, J. (1962). "Basic Mechanisms in Animal Virus Biology." Cold Spring Harbor Symp., 57, 479.

Huebner, R. J., Rowe, W. P., Turner, H. C., and Lane, W. T. (1963). Proc. nat. Acad. Sci., 50, 379.

Mannick, J. A., Graziani, J. T., and Egdhal, R. H. (1964). Transplantation, 2, 321.

Mellors, R. C., Heimer, R., Corcos, J., and Korngold, L. (1959). J. exp. Med., 110, 875.

Murphy, G. E., and Swift, H. F. (1949). Ibid., 89, 687.

Nossal, G. J. V., Ada, G. L., and Austin, C. M. (1964). Aust. J. exp. Biol. med. Sci., 42, 311.

Pekin, T. J., and Zvaifler, N. J. (1964). J. clin. Invest., 43, 1372.

Rodman, W. W., Williams, R. C., Bilka, P. J., and Müller-Eberhard, H. J. (1964). Arthr. and Rheum., 7, 749.

Simonsen, M. (1962). Progr. Allergy, 6, 349.

Stastny, P., Stembridge, V. A., and Ziff, M. (1963). J. exp. Med., 118, 635.

Thompson, M., and Bywaters, E. G. L. (1962). Ann. rheum. Dis., 21, 370.

Townes, A. S., Stewart, C. R., and Osler, A. G. (1962). In "Mechanism of Cell and Tissue Damage Produced by Immune Reactions". "Second int. Symp. on Immunopath. U.S.A., 1961", ed. P. Grabar and P. Miescher, p. 315. Schwabe, Basel.

\section{Quelques aspects immunologiques des maladies du tissu conjonctif}

\section{RÉSUMÉ}

1. Lorsqu'on crée un animal expérimental dont les cellules compétentes immunologiquement sont obligées à réagir in vivo avec les antigènes de leur hôte, des lésions inflammatoires se développent. Des lésions observées dans les articulations et dans le coeur semblent être le résultat d'une réaction entre la cellule étrangère et l'antigène de l'hôte; mais la possibilité qu'elles soient une conséquence d'une réaction d'hypersensibilité contre un agent infectieux doit être considérée. Cette question irrésolue se pose aussi lorsqu'on considère la maladie du tissu conjonctif humain, où la maladie homologue en peut être un modèle.

2. La membrane synoviale, avec sa couche de cellules phagocytaires de revêtement peut être potentiellement capable de fonctionner comme siège de l'immunisation primaire, menant à l'infiltration de ses couches plus profondes par des cellules mononucléaires à conséquence de l'absorption d'antigène de l'espace synovial. En présence d'une hypersensibilité établie, elle peut aussi être le siège de la prolifération des cellules sensibilisées. A cet égard, la membrane synoviale aurait des traits communs avec le ganglion lymphatique et, comme le ganglion lymphatique, elle pourrait être maintenue en un état d'activité chronique à un endroit anatomiquement localisé par la disponibilité constante d'antigène à cet endroit.

3. Des signes d'interaction directe entre les cellules synoviales et les lymphocytes dans la membrane synoviale rhumatoïde ne furent pas observés au microscope électronique. Des données présentes font penser à l'existence d'un antigène dans le liquide synovial ou en contact avec celui-ci. Cet antigène peut être un constituant autologue, mais on ne saurait écarter la possibilité d'un agent infectieux dans ce rôle.

4. La formation de l'auto-anticorps dans l'arthrite rhumatismale tend à se caler au niveau de la réponse primaire de 19S, ce qui n'est pas incompatible avec le caractère histologique du processus inflammatoire rhumatoïde et sa tendence à demeurer localisé. Par contre, le malade atteint de lupus érythémateux disséminé tend à produire un certain nombre d'anticorps sériques; ceux-ci semblent exister à un titre relativement élevé et subir une transition relativement prononcée à la forme 7S. Les traits cliniques et sérologiques de cette maladie sont, de plus, compatibles avec la présence de plus fortes quantités d'anticorps 7S dans le sang. On pense que les différences dans la formation des anticorps sériques entre l'arthrite rhumatismale et le lupus érythémateux disséminé représentent une variation de la réponse de l'hôte.

Algunos apectos inmunológicos de las enfermedades del tejido conectivo

\section{SUMARIO}

1. Cuando se crea un animal experimental cuyas células inmunológicamente competentes se ven obligadas a reaccionar in vivo con los antígenos de su huésped, lesiones inflamatorias se desarrollan. Las lesiones observadas en las articulaciones y en el corazón parecen ser el resultado de una reacción entre la célula extraña y el antígeno del huésped; pero la posibilidad de que estas lesiones sean una consecuencia de una reacción de hipersensibilidad contra un agente infeccioso debe tomarse en consideración. Esta cuestión irresuelta surge también al considerar la enfermedad del tejido conectivo, en que la enfermedad homóloga puede servir de modelo.

2. La membrana sinovial, con su capa de células fagocitarias de revestimiento es potencialmente capaz de funcionar como el sitio de inmunización primaria, llevando a la infiltración de sus capas más profundas por células mononucleares a consecuencia de absorpción de antígeno del espacio sinovial. En presencia de una hipersensibilidad establecida, peude también ser el sitio de la proliferación de las células sensibilizadas. En este respecto, la membrana sinovial tiene quizás carácteres comunes con los ganglios linfáticos $\mathrm{y}$, como los ganglios linfáticos, puede mantenerse $€ n$ un estado de actividad crónica en un lugar anatómicamente localizado por la disponibilidad constante en tal lugar del antígeno.

3. Signos de interacción directa entre las células sinoviales y los linofocitos en la membrana sinovial reumatoide no fueron observados al microscopio electrónico. Datos disponibles sugieren la existencia de un 
antígeno en el líquido sinovial o en contacto con éste. Este antígeno puede ser un constituyente autólogo, pero no se puede eliminar la posibilidad de que se trate de un agente infeccioso.

4. La formación del autoanticuerpo en la artritis reumatoide tiende a pararse al nivel de la respuesta primaria de 19S, lo que es compatible con el caràcter histológico del proceso inflamatorio reumatoide y con su tendecia a permanecer localizado. En cambio, el enfermo con lupus eritematoso diseminado tiende a producir un cierto número de anticuerpos séricos; estos parecen existir en concentraciones relativamente altas y sufrir una transición relativamente pronunciada a la forma 7S. Los rasgos clínicos y serológicos de esta enfermedad son, además, compatibles con la presencia de proporciones más fuertes del anticuerpo $7 \mathrm{~S}$ en la sangre. Se sugiere que las diferencias en la formación de anticuerpos séricos entre la artritis reumatoide y el lupus eritematoso diseminado representan una variación de la respuesta del organismo huésped. 